\title{
Islamic Integrated-Based School Principal Decision Making In Junior High School
}

\author{
Vinda Devi Yana ${ }^{1 凶}{ }^{\circledR}$ Asmendri $^{2}$ \\ Manajemen Pendidikan Islam, Institut Agama Islam Negeri Batusangkar, Indonesia ${ }^{1,2}$ \\ email: vindadeviana08gmail.com ${ }^{1}$, asmendri@iainbatusangkar.ac.id ${ }^{2}$
}

\begin{tabular}{ll}
\hline Article info & \multicolumn{1}{c}{ Abstract } \\
\hline & School principal decision-making is essentially a change in certain conditions. \\
ArticleHistory & The purpose of this study was to describe the process of Islamic integrated-based \\
Recieved: & decision-making by the junior high school principals. Descriptive qualitative was \\
$06 / 03 / 2021$ & chosen as the method of the research. Sources of data in this study were \\
Accepted: & principal, vice-principal, head of administration, and teachers at SMP IT Qurrata \\
$04 / 05 / 2021$ & A'yun Batusangkar. The data were collected using observation, interview, and \\
Published: & documentation techniques. The result of the study described that making \\
$10 / 05 / 2021$ & decisions in an education organization could run well by doing the right \\
& procedures of analyzing problems, developing solution alternatives, making \\
$\square$ & decisions after discussion, implementing the decision, and evaluating. The \\
Correspondingauthor & principal's decision-making is a determinant of strategic policies in realizing \\
& programs at his/her school.
\end{tabular}

Keywords: Decision Making, Principal, Islamic Integrated Junior High School

\begin{abstract}
Abstrak
Keputusan yang diambil kepala sekolah hakikatnya perubahan yang ada pada kondisi yang pasti. Tujuan Penelitian ini untuk mendeskripsikan proses pelaksanaan kegiatan yang dilakukan kepala sekolah dalam pengambilan keputusan di sekolah menengah pertama berbasis islam terpadu. Penelitian ini merupakan penelitian kualitatif dengan metode deskriptif. Penelitian dilakukan di SMP-IT Qurrata A'yun Batusangkar, Kabupaten Sungayang Tanah Datar. Sumber data dalam penelitian ini adalah Kepala Sekolah, wakil Kepala Sekolah, Kepala TU, dan Guru-Guru. Teknik pengumpulan data yang digunakan adalah observasi, wawancara dan dokumentasi. Hasil penelitian menemukan bahwa pengambilan keputusan dalam suatu organisasi pendidikan dapat berjalan dengan baik melalui prosedur pengambilan keutusan yang benar dengan cara menganalisis masalah, mengembangkan alternatif solusi, memutuskan alternatif berdasarkan musyawarah, pengimplementasian keputusan yang diambil dan evaluasi. Pengambilan keputusan kepala sekolah menjadi penentu dalam kebijakan-kebijakan strategis dalam mewujudkan program-program di stauan pendidikan yang dipimpinnya.
\end{abstract}

Kata Kunci: Pengambilan Keputusan, Kepala Sekolah, SMP Islam Terpadu

JIES is licensed under a Creative Commons Atribution-Share Alike 4.0 Internasional Licence

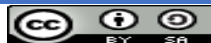

\section{PENDAHULUAN}

Kepala sekolah ialah kedudukan yang memiliki wewenang dalam membuat ketetapan serta terletak pada posisi paling atas dalam sesuatu organisasi satuan 
pendidikan (Bento \& Ribeiro, 2013; Mendels, 2012; Nai \& Wijayanti, 2018). Permendiknas RI No. 19 Tahun (2007) tentang "Standar Pengelolaan Pendidikan yang menjelaskan bahwa setiap sekolah/madrasah dipimpin oleh seorang kepala sekolah/madrasah". Oleh karena itu penempatan posisi atau kedudukan jabatan tertinggi dalam suatu organisasi pendidikan dipegang oleh kepala sekolah.

Kepala sekolah merupakan pembuat kebijakan dan pembuat keputusan dalam organisasi yang dipimpinnya. Pengambilan keputusan yang di lakukan oleh kepala sekolah hendaknya dilakukan melalui proses dan prosedur pengambilan keputusan (Nasrullah et al., 2017; Permadani et al., 2018). Menurut Munthe (2018), Apabila sekolah tidak ditopang oleh siklus pengambilan keputusan yang benar, maka semua kerangka kerja yang ada di sekolah tidak akan berjalan dengan mudah atau akan ada banyak kendala yang menyebabkan tujuan pembelajaran tidak dapat dicapai secara ideal. Sejalan dengan pendapat tersebut, penelitian yang dilakukan oleh Ayub \& Syukri (2014), menyatakan bahwa keberanian kepala sekolah dalam mengambil keputusan sangat diperlukan untuk memberikan keputusan yang cepat tepat dan tanpa ragu-ragu. Dengan keberanian, maka kepala sekolah mempunya kepercayaan diri yang kuat untuk mengatasi setiap kesulitan dan kegagalan.

Hasil penelitian lain Octavia \& Savira, (2017), juga menyebutkan bahwa berhasil atau tidak jalannya program-program yang dimiliki sekolah ditentukan oleh kepemimpinan kepala sekolah, sebagai penentu dan pengendali arah kebijakan di satuan organisasi satuan pendidikan yang di pimpinnya. Pengambilan keputusan kepala sekolah sebagai pemimpin akan membawa pengaruh besar terhadap keberlanjutan sekolah (Supriadi \& Rejokirono, 2020). Kepala sekolah sebagai pemimpin dapat menetapkan langkah-langkah apa yang semestinya diambil untuk memperoleh arah sekolah untuk berkembang, dan harus melakukan pembinaan dan pengelolaan terhadap komponen sekolah baik itu melalui kegiatan administrasi, manajemen dan kepemimpinan yang sangat tergantung pada kemampuan manajerial seorang kepala sekolah (Trisharsiwi \& Sumiyati, 2020).

Setiap pengambilan keputusan, kepala sekolah membutuhkan informasi terlebih dahulu terhadap permasalahan yang terjadi, karena dengan data-data yang diperoleh maka alternatif terhadap pemecahan masalah bisa lebih efektif dan efisien. Informasi tersebut diperoleh dari seluruh unsur stakeholder yang ada (Budiono \& Wibowo, 2014). 
Dengan demikian kepala sekolah dapat mengetahui secara cepat maju mundurnya serta peluang dari sekolah untuk lebih baik dalam pengelolaannya.

Hasil penelitian Syafa'at Ariful Huda et al., (2019), menemukan bahwa “1) Terdapat pengaruh positif langsung dari kecakapan manajerial terhadap pengambilan keputusan kepala sekolah, 2) terdapat pengaruh positif langsung kreativitas terhadap pengambilan keputusan kepala sekolah dan 3) terdapat pengaruh positif langsung kecakapan manajerial terhadap kreativitas".

Berdasarkan observasi observasi awal ke sekolah SMP-IT Qurrata A'yun Batusangkar dan melakukan wawancara dengan kepala sekolah, wakil kepala sekolah, kepala TU, dan guru-guru untuk mengetahui seperti apa pelaksanaan pengambilan keputusan yang dilakukan kepala sekolah. Berbagai kebijakan yang dilaksanakan oleh SMP-IT Qurrata A'yun, sudah terlaksana yaitu seperti peraturan-peraturan yang ada disekolah sudah berjalan dengan baik. Tentunya peranan kepala sekolah sangat besar ibarat seorang nahkoda untuk memotivasi, menggerakkan, dan membuat keputusan menjadi salah satu pendorong keberhasilan prestasi di SMP-IT Qurrata A'yun.

Berdasarkan kenyataan-kenyataan di atas, maka dapat dilihat bahwa begitu pentingnya pengambilan keputusan yang dilakukan oleh kepala sekolah demi kemajuan sekolah dan maka penelitian ini perlu dilakukan. Maka dari itu, peneliti tertarik untuk mengadakan penelitian yang lebih mendalam terhadap proses pelaksanaan kegiatan yang dilakukan kepala sekolah dalam suatu pengambilan keputusan dan kendalakendala yang dihadapi dalam pengambilan keputusan dalam suatu organisasi pendidikan.

\section{METODE PENELITIAN}

Jenis penelitian berupa penelitian lapangan (field reserch) dengan menggunakan metode kualitatif deskriptif. Pendekatan deskriptif ini akan menggambarkan bagaimana berbagai situasi dan kejadian yang di ada di lokus penelitian.

Penelitian diadakan di SMP-IT Qurrata A'yun Batusangkar Parik Balai Diateh Sungayang Kabupaten Sungayang Tanah Datar. Sumber data dalam penelitian ini adalah Kepala Sekolah, wakil Kepala Sekolah, Kepala TU, dan Guru-Guru. Penelitian ini terdapat tiga cara dalam mengumpulkan data, yakni observasi, wawancara dan dokumentasi. 
Analisis data terdiri dari empat tahapan, yakni: mengumpulkan data dengan melakukan penyaringan data-data penting berhubungan dengan masalah yang akan dikaji. Selanjutnya menyajikan data, dengan cara informasi data yang diperoleh disusun dalam bentuk narasi. Terakhir adalah penarikan kesimpulan dan verifikasi data. Teknik keabsahan data menggunakan Triangulasi. Tahapan Tersebut dapat dilihat pada gambar berikut:

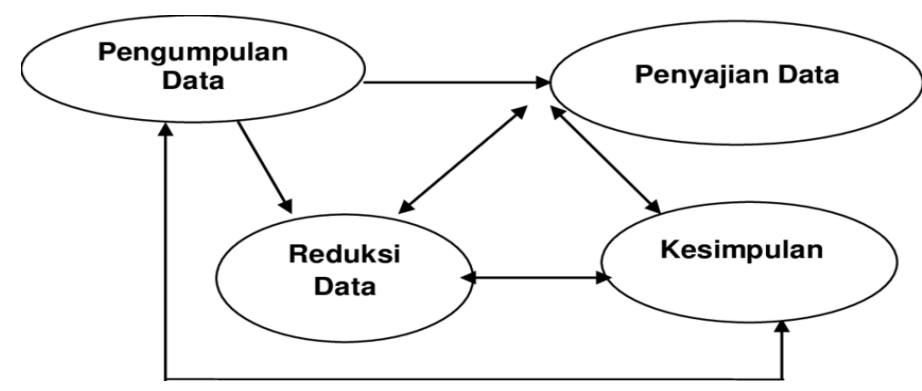

Gambar 1. Tahapan Analisis Data

\section{HASIL DAN PEMBAHASAN}

\section{Proses pelaksanaan kegiatan yang dilakukan kepala sekolah dalam suatu pengambilan keputusan di SMP-IT Qurrata A'yun Batusangkar}

Proses pelaksanaan pengambilan keputusan yang dibuat kepala sekolah sebelumnya melakukan rapat dengan GTK. Dari rapat tersebut akan menghasilkan poinpoin yang menjadi kesepakatan dan ditetapkan sebagai keputusan. Apabila sifatnya mendesak dan harus segera ada keputusan, maka sebagai kepala sekolah di SMP-IT Qurrata A'yun akan mengambil keputusan dan membuat sebuah kebijakan tanpa adanya rapat agar kegiatan di sekolah ini tetap efektif, tentunya dengan memperhatikan dan mempertimbangkan seluruh regulasi dan peraturan yang berlaku untuk kemaslahatan bersama.

Dalam pelaksanaan pengambilan keputusan kepala SMP-IT Qurrata A'yun selaku pemimpin, berusaha semaksimal mungkin untuk menjadi teladan untuk melaksanakan keputusan yang sudah diambil. Keputusan tersebut seperti tupoksi kepala sekolah, yaitu berkaitan dengan hal keuangan, kurikulum, personalia, kedisiplinan, dan lain-lain. Selain menjadi contoh teladan yang baik, kepala sekolah dalam pelaksanaan keputusan juga menjadi leader, supervisior, administrator, manajer, dan lain-lain. Dalam 
pelaksanaan pengambilan keputusan, yang menjadi faktor pendukungnya, yaitu GTK/personil serta adanya kebutuhan dan permintaan.

Dalam proses pengambilan keputusan yang dilakukan oleh kepala sekolah SMPIT Qurrata A'yun, kepala sekolah melakukannya dengan cara musyawarah dengan melibatkan stakeholder. Sebagai pemimpin, kepala sekolah memberikan kesempatan kepada stakeholder untuk menyampaikan kritik dan sarannya. Semua ikut andil dalam proses pengambilan keputusan, sehingga menghasilkan keputusan yang disepakati bersama dan menjadi kebijakan yang diputuskan oleh kepala sekolah. Jika kepala sekolah mengambil keputusan tersendiri, maka saya selaku wakil akan menanyakan langsung atau meninjau ulang kembali kepada kepala sekolah jika keputusan itu memihak pada suatu hal.

Dalam pelaksanaan pengambilan keputusan kepala sekolah dibantu oleh wakil untuk menganalisis keputusan yang sudah dimusyawarahkan sebelumnya dengan memberikan ide dan masukan yang pastinya untuk kebaikan sekolah. Kepala sekolah juga dapat memanfaatkan peluang yang ada dengan baik baik dalam pengambilan keputusan maupun dalam pelaksanaannya. Jika kebijakan atau keputusan yang diambil telah direalisasikan, maka kepala sekolah akan melakukan evaluasi dengan melakukan rapat dengan mengajak pihak terkait dengan pelaksanaan keputusan tersebut.

Proses pengambilan keputusan yang dilakukan oleh kepala sekolah SMP-IT Qurrata A'yun, kepala sekolah melakukannya dengan cara musyawarah dengan dua cara yaitu: (1) Musyawarah di tingkat pimimpin sekolah (Kepala sekolah, Wakil (kurikulum, sarana prasarana, kesiswaan, dan pengasuhan), Kepala TAS, Koordinasi Asrama berserta koordinator bahasa dan Tahfidz. (2) Musyawarah dengan seluruh GTK, dengan cara musyawarah berkala 1 bulan sekali, dan musyawarah tidak berkala (ketika ada yang hal penting yang harus di musyawarahkan). Dalam bermusyawarah, kepala sekolah selalu memberikan kesempatan memberikan ide dan mendengarkan pendapat seluruh GTK.

Dalam pelaksanaan pengambilan keputusan, kepala sekolah memanfaatkan peluang yang ada di sekolah dengan meminta pandangan atau pertimbangan dari semua pihak agar pelaksanaannya dapat berjalan dengan tepat dan baik. Biasanya kepala sekolah terlebih dahulu dalam pelaksanaan akan melakukan rapat pimpinan, rapat GTK, dan hasilnya akan disampaikan ke yayasan agar dapat segera direalisasikan. Dalam 
melaksanakan keputusan, para anggota atau para guru sangat mendukung dan setuju dengan cara kepala sekolah dalam melaksanakan keputusannya, apalagi kepala sekolah juga sering melakukan evaluasi terhadap keputusan yang telah diambil baik itu dengan cara pengawasan langsung maupun melalui rapat evaluasi. Adapun yang terlibat dalam pengevaluasian dan sekaligus menjadi pendukung pelaksanaan pengambilan keputusan yaitu: Kepala Sekolah, Wakil Kepala Sekolah, Kepala TU/TAS, Koordinator Asrama dan bahasa, serta GTK. Jadi, saya dapat mengemukakan bahwa keputusan yang telah diambil kepala sekolah selama ini sudah efektif karena selalu di musyawarahkan.

Dalam proses pengambilan keputusan yang dilakukan oleh kepala sekolah SMPIT Qurrata A'yun, kepala sekolah selalu mengambil putusan melalui musyawarah, dilakukan sesuai prosedur dan selalu berdasarkan pertimbangan dari anggotanya, baik itu pengambilan keputusan dalam rapat pimpinan, rapat bulanan majelis guru, rapat darurat dan ada yang bersifat kontemporer. Dalam pengambilan keputusan, kepala sekolah sangat arif dan bijaksana serta beliau menampung seluruh opini atau pendapat yang disampaikan GTK.

Dalam pelaksanaan pengambilan keputusan, kepala sekolah bersikap arif dan bijaksana dan bekerjasama dengan semua pihak terkait dalam pelaksanaannya. Kepala sekolah selalu memantau setiap keputusan yang dibuatnya, seperti melaksanakan study class untuk persiapan OSN, pelatihan-pelatihan lainnya untuk persiapan lomba, melatih guru untuk paham semua lini ADM sekolah dan IT, serta hal-hal yang lain yang telah diputuskan oleh kepala sekolah. Kepala sekolah, juga melakukan evaluasi terhadap pelaksanaan keputusan tersebut, dengan cara memanggil pihak terkait, melakukan rapat, dan terkadang kepala sekolah melakukannya dengan melakukan chat atau pesan melalui aplikasi pesan digital. Dalam pelaksanaan pengambilan keputusan yang menjadi faktor pendukung kepala sekolah adalah Pihak yayasan, wakil kepala sekolah, Kepala TAS/TU, koordinator asrama dan bahasa, serta GTK. Kepala sekolah akan memberikan semangat dan akan terjun langsung jika ada kesulitan dalam pelaksanaannya.

Dalam dunia pendidikan diperlukan suatu terobosan untuk mewujudkan tujuan pendidikan yaitu dengan cara meningkatkan fungsi dan peran kepala sekolah. Hal ini dilakukan dengan tujuan menciptakan sekolah sebagai lingkungan pendidikan yang dapat menghasilkan lulusan dengan beragam tingkat pengetahuan, kemampuan, nilai dan sikap yang memungkinkannya menjadi warga masyarakat dan negara yang 
bertakwa terhadap Tuhan Yang Maha Esa, beriman dan berbudi pekerti luhur. Dalam mewujudkan itu semua, tidak terlepas dari keputusan yang diambil oleh kepala sekolah dan pelaksanaannya.

Hasil temuan penelitian ini sejalan dengan temuan penelitian oleh Susanto (2016) "Pengambilan keputusan rasional memiliki hubungan positif dengan akuntabilitas. Makin tinggi pengambilan keputusan rasional, maka akan semakin tinggi pula akuntabilitas, yang berarti bahwa dengan pengambilan keputusan rasional yang tinggi berarti akuntabilitas juga tinggi. Dengan demikian, pengambilan keputusan rasional merupakan salah satu faktor yang harus diperhatikan untuk meningkatkan akuntabilitas."

Menurut Muhdi et al., (2017), Keterlibatan anggota suatu organisasi dalam mengambil keputusan adalah hal yang penting, karena dengan melibatkan seluruh proses pengambilan keputusan, anggota organisasi akan merasa dihargai sehingga akan mengembangkan perilaku pelaksanaan keputusan. Dalam proses pengambilan keputusan Primasasari (2014), menyatakan bahwa tahapan pengambil keputusan dimulai dari mengiidentifikasi masalah yang ada, merumuskan tujuan, mencarikan solusi pemecahan masalah, membuat kriteria dari setiap alternatif solusi dan terakhir menentukan pilihan dari alternatif solusi (keputusan). Hal ini sejalan dengan hasil penelitian Putra (2014), bahwa dalam proses pengambilan keputusan oleh kepala sekolah harus dilakukan secara sistematis, terprogram dan juga mendorong para guruguru untuk selalu aktif dan kreatif guna menumbuhkan rasa tanggung jawab bersama.

\section{Kendala-kendala yang ditemukan oleh kepala sekolah dalam pelaksanaan pengambilan keputusan di SMP-IT Qurrata A'yun Batusangkar}

Pelaksanaan pengambilan keputusan, terkadang semua keputusan tidak terlaksana dengan lancar dan terkadang faktor pendukung bisa menjadi faktor penghambat seperti keterbatasan personil dan biaya. Dalam mengatasi kendala-kendala tersebut biasanya saya akan membicarakan dengan GTK terkait, terkait dengan biaya biasanya saya akan koordinasikan dengan yayasan dan terkadang juga dengan orang tua santri. Jika terjadi konflik terkait dengan keputusan yang telah diambil, maka saya akan memanggil orang terkait untuk tabayun, kemudian setelah mengetahui akar masalahnya maka akan dilakukan pembinaan dan islah. 
Pengambilan dan pelaksanaan keputusan biasanya terjadi kendala atau penghambat yaitu terjadinya benturan pada hal yang diputuskan karena kurang komunikasi. Untuk mengatasi masalah tersebut, kepala sekolah akan meminta pendapat dan masukan dari jajaran pimpinan, dan saya selaku wakil biasanya akan membantu kepala sekolah dalam menganalisis apa yang menjadi penghambat tersebut. Setelah itu, kepala sekolah melakukan evaluasi ulang dan melakukan inovasi-inovasi untuk kebaikan di kemudian hari.

Dalam pelaksanaan pengambilan suatu keputusan tentunya pasti ada kendalakendala yang dihadapi. Pada pelaksanaan pengambilan keputusan di sekolah ini, bisa dikatakan tidak ada faktor penghambat, karena semua pihak di SMP IT Qurrata A'yun siap siaga dan taat pada kepala pimpinan yaitu kepala sekolah. Apalagi semua kebijakan dan pelaksanaan keputusan sudah mendapatkan dukungan dari yayasan. Dalam pelaksanaan pengambilan keputusan, faktor penghambat yang ditemui kepala sekolah biasanya adalah keterbatasan waktu, kurangnya koordinasi sesama anggota, adanya guru yang sakit dan kurangnya pemahaman guru akan tugasnya, ketidak setujuan dari orang tua, serta perubahan kondisi dilapangan. Apabila itu semua akan mengganggu pelaksanaan dan dapat menimbulkan konflik maka kepala sekolah akan mengadakan rapat atau musyawarah untuk mencari solusinya dengan wakil, kepala TU dan semua GTK.

Dari semua hasil wawancara yang peneliti jabarkan di atas mengenai hambatan atau kendala yang ditemukan kepala sekolah dalam pelaksanaan pengambilan keputusan, maka dapat dikatakan bahwa faktor penghambat pelaksanaan yaitu keterbatasan personil, keterbatasan biaya, kurangnya komunikasi, kurangnya koordinasi sesama anggota, ada yang sakit dan kurangnya pemahaman guru akan tugasnya, tidak setujunya orang tua akan perubahan kondisi di lapangan. Semua kendala tersebut dapat diatasi oleh kepala sekolah dan jajaran dengan membicarakan dengan pihak terkait, terkait dengan biaya akan dikoordinasikan kepada pihak yayasan dan orang tua santri, melakukan musyawarah dengan jajaran pimpinan dan GTK. Setelah itu, kepala sekolah akan menganalisisnya bersama para wakil, dan melakukan evaluasi ulang serta melakukan inovasi-inovasi untuk kebaikan di kemudian hari.

Berdasarkan hasil penelitian terhadap Pelaksanaan Pengambilan Keputusan oleh Kepala Sekolah di SMP-IT Qurrata A'yun Batusangkar bahwa pelaksanaannya 
sudah berjalan dengan baik, jelas dan terarah. Bila dilihat dari kerja sama tim, semua pihak bertanggung jawab pada peran dan tugasnya yaitu kepala sekolah, Wakil Kepala Sekolah, TU, dan Guru terlibat dalam meningkatkan kualitas pendidikan. Adapun penjabaran dalam pembahasan ini berpedoman pada pertanyaan penelitian tentang:

Menurut Victorynie (2015), dalam hasil penelitiannya terdapat beberapa masalah yang diidentifikasi berdasarkan peresepsi guru berkenaan dengan pengambilan keputusan oleh kepala sekolah adalah sebagai berikut: “(1) Kurangnya keikutsertaan guru dalam setiap proses pembuatan keputusan; (2) Pengambilan keputusan yang dilakukan kepala sekolah masih kurang efektif karena kurangnya pertimbangan mutu dan penerimaan guru; (3) Kurangnya data dan informasi yang digunakan dalam proses pembuatan keputusan; (4) Kurangnya penyesuaian kepala sekolah terhadap situasi dan kondisi baru sebelum membuat keputusan, dan (5) Kepala sekolah terburu-buru dalam mengambil keputusan dan kurang melaksanakan langkah-langkah yang tepat".

Kendala-kendala yang dihadapi kepala sekolah dalam pelaksanaan terletak pada keterbatasan personil, keterbatasan biaya, miss komunikasi, kurangnya koordinasi sesama anggota, ada yang sakit dan kurangnya pemahaman guru akan tugasnya, ketidaksetujuan orang tua dan perubahan kondisi di lapangan. Semua kendala tersebut dapat diatasi oleh kepala sekolah dan jajaran dengan membicarakan dengan pihak terkait, terkait dengan biaya akan dikoordinasikan kepada pihak yayasan dan orang tua santri, melakukan musyawarah dengan jajaran pimpinan dan GTK. Setelah itu, kepala sekolah akan menganalisisnya bersama para wakil, dan melakukan evaluasi ulang serta melakukan inovasi-inovasi untuk kebaikan di kemudian hari.

Berdasarkan penjelasan tersebut, Menurut Machali, (2018), keterlibatan kelompok menjadi kendala yang sering ditemui. Karena melibatkan banyak orang dalam proses pelaksanaan pengambilan keputusan, kendala utama yang ditimbulkan karena keinginan pihak-pihak yang terlibat, sering timbulnya perbedaan pandangan di antara mereka yang terlibat.

\section{KESIMPULAN}

Secara garis besar proses pengambilan keputusan yang dilakukan oleh kepala SMP-IT Qurrata A'yun menunjukkan bahwa proses pengambilan keputusan dilakukan dengan cara menganalisis masalah, mengembangkan alternatif solusi, memutuskan 
alternatif berdasarkan musyawarah, pengimplementasian keputusan yang diambil dan evaluasi. Proses pengambilan keputusan dalam partisipasi organisasi sekolah merupakan aspek manajerial yang baik. Maka permasalahan yang ada dalam organisasi dapat diselesaikan oleh kepala sekolah dengan semua anggota organisasi dengan cara yang efektif dan efesien. Dengan demikian, posisi kepala sekolah sebagai pengambil keputusan (Decision Making) sudah maksimal melakukan tugasnya sebagai pemimpin yang baik dengan selalu memusyawarahkan keputusan yang akan diambilnya, meninjau dan memantau proses dan pelaksanaan keputusannya, melakukan evaluasi serta tindak lanjut terhadap pelaksanaan pengambilan keputusan tersebut.

\section{DAFTAR PUSTAKA}

Ayub, U., \& Syukri, M. (2014). Profil Kepemimpinan Kepala Sekolah Dalam Pengambilan Keputusan Pada Pelaksanaan Manajemen Berbasis Sekolah. Jurnal Pendidikan Dan Pembelajaran, 3(7), 1-16.

Bento, A. V., \& Ribeiro, M. I. (2013). Authentic Leadership in School Organizations. European Scientific Journal, 9(31), 1857-7881.

Budiono, B., \& Wibowo, U. B. (2014). Pengaruh Komunikasi Organisasi, Kecerdasan Emosi Dan Pengambilan Keputusan Terhadap Implementasi Peran Kepemimpinan Kepala Sd. Jurnal Akuntabilitas Manajemen Pendidikan, 2(2), 147-158. https://doi.org/10.21831/amp.v2i2.2445

Machali, I. (2018). The Handbook of Education Management: Teori dan Praktik Pengelolaan Sekolah/Madrasah di Indonesia. Prenada Media.

Mendels, P. (2012). The Effective Principal. Leaderhip Journal, 33(1), 54-57.

Muhdi, M., Kastawi, N. S., \& Widodo, S. (2017). Teknik Pengambilan Keputusan Dalam Menentukan Model Manajemen Pendidikan Menengah. Kelola: Jurnal Manajemen Pendidikan, 4(2), 135. https://doi.org/10.24246/j.jk.2017.v4.i2.p135145

Munthe, A. R. S. (2018). Peran Kepala Sekolah dalam Pengambilan Keputusan untuk Meningkatkan Mutu Pendidikan di MTS Cerdas Murni Tembung. [UIN Sumatera Utara. Medan.]. http://repository.uinsu.ac.id/3899/

Nai, H., \& Wijayanti, W. (2018). Pelaksanaan tugas dan fungsi kepala sekolah pendidikan menengah negeri. Jurnal Akuntabilitas Manajemen Pendidikan, 6(2), 183. https://doi.org/10.21831/amp.v6i2.10182

Nasrullah, M., Rumingan, M., \& Niswaty, N. N. R. (2017). Pengaruh Pengambilan 
Keputusan Kepala Sekolah terhadap Kinerja Guru di SMK Negeri 1 Makassar. Jurnal Ad'ministrare, 4(2), 103-110. https://doi.org/https://doi.org/10.26858/ja.v4i2.5993

Octavia, L. S., \& Savira, S. I. (2017). Gaya Kepemimpinan Kepala Sekolah dalam Upaya Meningkatkan Kinerja Guru dan Tenaga Kependidikan. Jurnal Dinamika Manajemen Pendidikan, 1(1), 7. https://doi.org/10.26740/jdmp.v1n1.p7-14

Permadani, D. R., Maisyaroh, M., \& Mustiningsih, M. (2018). Kepemimpinan Kepala Sekolah Dalam Pembuatan Keputusan. Jurnal Administrasi Dan Manajemen Pendidikan, 1(3), 320-326. https://doi.org/10.17977/um027v1i32018p320

PermendiknasRI. (2007). Peraturan Menteri Pendidikan Nasional Republik Indonesia Nomor 13 Tahun 2007 Tentang Standar Kepala Sekolah/Madrasah. 1(1), 1-17. https://bsnp-indonesia.org/id/wp-content/uploads/tenaga/Permen_13_Th-2007.pdf

Primasasari, P. S. D. (2014). Manajemen Stratejik \& Pengambilan keputusan Korporasi (Strategic Management\& Corporate Decision Making). PT. Bumi Aksara.

Putra, V. M. (2014). Persepsi Guru Terhadap Pengambilan Keputusan. Jurnal Administrasi Pendidikan, 2(1), 755-831. http://ejournal.unp.ac.id/index.php/bahana/article/view/3822

Supriadi, D., \& Rejokirono, R. (2020). Efektivitas Pengambilan Keputusan Kepala Sekolah SMK di Yogyakarta. SOSIOHUMANIORA: Jurnal Ilmiah Ilmu Sosial Dan Humaniora, 6(2), 32. https://doi.org/10.30738/sosio.v6i2.8019

Susanto, R. (2016). Hubungan Pengambilan Keputusan Rasional Dengan Akuntabilitas Kepemimpinan Kepala Sekolah. Eduscience -, 2(1), 22-38.

Syafa'at Ariful Huda, Purwani Puji Utami, Chairunnisa, \& Illah Sailah. (2019). Analisis Pengambilan Keputusan Kepala Sekolah Smp Negeri Kabupaten Dan Kota Tangerang. Visipena Journal, $10(1), \quad 113-126$. https://doi.org/10.46244/visipena.v10i1.494

Trisharsiwi, T., \& Sumiyati, Y. (2020). Karakteristik Metode Pengambilan Keputusan Kepala Sekolah. WACANA AKADEMIKA: Majalah Ilmiah Kependidikan, 4(2), 83. https://doi.org/10.30738/wa.v4i2.7451

Victorynie, I. (2015). Pemberdayaan Guru Dalam Mendukung Pengambilan Keputusan Kepala Sekolah Dasar. Pedagogik, 3(1), 89-101. 